\title{
A Late Pleistocene sea level stack
}

\author{
Rachel M. Spratt and Lorraine E. Lisiecki \\ Department of Earth Science, University of California, Santa Barbara, California, USA \\ Correspondence to: Lorraine E. Lisiecki (lisiecki@geol.ucsb.edu)
}

Received: 7 July 2015 - Published in Clim. Past Discuss.: 13 August 2015

Revised: 26 February 2016 - Accepted: 18 March 2016 - Published: 26 April 2016

\begin{abstract}
Late Pleistocene sea level has been reconstructed from ocean sediment core data using a wide variety of proxies and models. However, the accuracy of individual reconstructions is limited by measurement error, local variations in salinity and temperature, and assumptions particular to each technique. Here we present a sea level stack (average) which increases the signal-to-noise ratio of individual reconstructions. Specifically, we perform principal component analysis (PCA) on seven records from 0 to $430 \mathrm{ka}$ and five records from 0 to $798 \mathrm{ka}$. The first principal component, which we use as the stack, describes $\sim 80 \%$ of the variance in the data and is similar using either five or seven records. After scaling the stack based on Holocene and Last Glacial Maximum (LGM) sea level estimates, the stack agrees to within $5 \mathrm{~m}$ with isostatically adjusted coral sea level estimates for Marine Isotope Stages 5e and 11 (125 and $400 \mathrm{ka}$, respectively). Bootstrapping and random sampling yield mean uncertainty estimates of 9-12 m $(1 \sigma)$ for the scaled stack. Sea level change accounts for about $45 \%$ of the total orbitalband variance in benthic $\delta^{18} \mathrm{O}$, compared to a $65 \%$ contribution during the LGM-to-Holocene transition. Additionally, the second and third principal components of our analyses reflect differences between proxy records associated with spatial variations in the $\delta^{18} \mathrm{O}$ of seawater.
\end{abstract}

\section{Introduction}

Glacial-interglacial cycles of the Late Pleistocene (0-800 ka) produced sea level changes of approximately $130 \mathrm{~m}$, primarily associated with the growth and retreat of continental ice sheets in $100 \mathrm{ka}$ cycles. Recent ice sheet modeling studies support the assertion of Milankovitch theory that Late Pleistocene glacial cycles are primarily driven by insolation changes associated with Earth's orbital cycles (Ganopolski and Calov, 2011; Abe-Ouchi et al., 2013). However, modeling ice sheet responses over orbital timescales remains quite challenging, and the output of such models should be evaluated using precise and accurate reconstructions of sea level change. Thus, Late Pleistocene sea level reconstructions are important both for understanding the mechanisms responsible for $100 \mathrm{ka}$ glacial cycles and for quantifying the amplitude and rate of ice sheet responses to climate change. Sea level estimates for warm interglacials at 125 and $400 \mathrm{ka}$ are also of particular interest as potential analogs for future sea level rise (Kopp et al., 2009; Raymo and Mitrovica, 2012; Dutton et al., 2015).

Nearly continuous coral elevation data have generated well-constrained sea level reconstructions since the Last Glacial Maximum (LGM) at $21 \mathrm{ka}$ (Clark et al., 2009; Lambeck et al., 2014). However, beyond the LGM sea level estimates from corals are discontinuous and have relatively large age uncertainties (e.g., Thompson and Goldstein, 2005; Medina-Elizalde, 2013). Several techniques have been developed to generate longer continuous sea level reconstructions from marine sediment core data. Each of these techniques is subject to different assumptions and regional influences. Here, we identify the common signal present in seven Late Pleistocene sea level records as well as some of their differences.

These sediment core records convert $\delta^{18} \mathrm{O}_{\mathrm{c}}$, the oxygen isotope content of the calcite tests of foraminifera, to sea level using one of several techniques. In three records, temperature proxies were used to remove the temperaturedependent fractionation effect from $\delta^{18} \mathrm{O}_{\mathrm{c}}$ in order to solve for the $\delta^{18} \mathrm{O}$ of seawater $\left(\delta^{18} \mathrm{O}_{\mathrm{sw}}\right)$. Other techniques for transforming $\delta^{18} \mathrm{O}_{\mathrm{c}}$ to sea level include the polynomial regression of $\delta^{18} \mathrm{O}_{\mathrm{c}}$ to coral-based sea level estimates, hydraulic control models of semi-isolated basins, and inverse models of ice volume and temperature. Each of these tech- 
niques produce slightly different results for a variety of reasons. For example, $\delta^{18} \mathrm{O}_{\mathrm{sw}}$ varies spatially due to differences in water mass salinity and deep water formation processes (Adkins et al., 2002). Reconstructions also vary based on sensitivity to eustatic versus relative sea level (RSL) and temporal resolution.

Principal component analysis (PCA) is used to identify the common sea level signal in these seven records (i.e., to produce a sea level "stack") and to evaluate differences between reconstruction techniques. By combining multiple sea level records with different underlying assumptions and sources of noise, the sea level stack should have a higher signal-to-noise ratio than the individual sea level records used to construct it. We estimate the uncertainty of the sea level stack using bootstrapping and Monte Carlo-style random sampling. For comparison, we also report the standard deviation of highstand and lowstand estimates across individual records and the sea level uncertainties of individual records as estimated in their original publications. A probabilistic reassessment of the uncertainties in individual records is beyond the scope of the current study.

\section{Sea level reconstruction techniques}

\subsection{Corals and other coastal sea level proxies}

Corals provide the most prominent Late Pleistocene sea level proxy. They can be radiometrically dated and provide especially accurate sea level estimates between 0 and $21 \mathrm{ka}$ because of nearly continuous pristine coral specimens from several locations (Fairbanks, 1989; Bard et al., 1990, 1996; Edwards et al., 1993). Dated coral sea level estimates extend as far back as $\sim 600 \mathrm{ka}$ (Stein et al., 1993; Stirling et al., 1995; Medina-Elizalde, 2013; Muhs et al., 2014; Andersen et al., 2008). However, coral data are increasingly discontinuous and inaccurate prior to $21 \mathrm{ka}$ due to difficulty finding pristine and in situ older corals (particularly during sea level lowstands) and due to U-Th age uncertainties in older corals caused by isotope free exchange with the surrounding environment (e.g., Thompson and Goldstein, 2005; Blanchon et al., 2009; Medina-Elizalde, 2013). Interpretation of sea level from corals often requires a correction for rates of continental uplift, which may not be known precisely (Creveling et al., 2015). Glacial isostatic adjustment (GIA) and species habitat depth (up to $6 \mathrm{~m}$ below sea level) may also affect sea level estimates (Raymo and Mitrovica, 2012; Medina-Elizalde, 2013). Wave destruction and climate variations also alter coral growth patterns and may affect the height of colonies relative to sea level (Blanchon et al., 2009; Medina-Elizalde, 2013).

Organic proxies such as peat bogs and shell beds can also be used as sea level proxies and can be radiometrically dated (e.g., Horton, 2006). Geological formations indicating sea level such as abandoned beaches and sea cliffs can also be used as sea level proxies (Hanebuth et al., 2000; Boak and Turner, 2005; Bowen, 2010).

Corals and other coastal proxies are indicators of relative (local) sea level and, thus, are affected by in situ glacioisostatic effects, ocean siphoning processes, and other local effects of sea level rise and fall. However, their wide spatial distribution, particularly corals in tropical regions, allows for modeling of glacio-isostatic adjustments (GIA) to create a global estimate of mean sea level change (e.g., Kopp et al., 2009; Lambeck et al., 2014; Dutton and Lambeck, 2012; Hay et al., 2014). GIA models constrained by these coastal indicators provide robust sea level change estimates of -130 to $-134 \mathrm{~m}$ for the LGM (Clark et al., 2009; Lambeck et al., 2014). A compilation of dozens of corals and other sea level indicators also provide relatively well-constrained estimate of $8.7 \pm 0.7 \mathrm{~m}$ for peak global mean sea level at the last interglacial (Kopp et al., 2009). Estimates from multiple studies using different data are all in relatively good agreement yielding a consensus estimate of 6-9 m above modern (Dutton et al., 2015). Additionally, sea level during last interglacial likely experienced several meters of millennialscale variability (Kopp et al., 2013; Govin et al., 2012). Uncertainties increase for older interglacials. GIA-corrected coastal sea level proxies for Marine Isotope Stage (MIS) 11 at $\sim 400$ ka suggest a global mean sea level of 6-13 $\mathrm{m}$ above modern (Raymo and Mitrovica, 2012).

\subsection{Seawater $\delta^{18} \mathrm{O}$}

Global ice volume is a main control on the global mean of $\delta^{18} \mathrm{O}$ in seawater $\left(\delta^{18} \mathrm{O}_{\mathrm{sw}}\right)$, with global mean $\delta^{18} \mathrm{O}_{\mathrm{sw}}$ estimated to decrease by $0.008-0.01 \% \mathrm{~m}^{-1}$ of sea level rise (Adkins et al., 2002; Elderfield et al., 2012; Shakun et al., 2015). However, $\delta^{18} \mathrm{O}_{\mathrm{sw}}$ also varies spatially based on patterns of evaporation and precipitation and deep water formation processes. The $\delta^{18} \mathrm{O}$ of calcite $\left(\delta^{18} \mathrm{O}_{\mathrm{c}}\right)$ is affected both by the $\delta^{18} \mathrm{O}_{\mathrm{sw}}$ and temperature. In the absence of any post-depositional alteration, subtracting the temperaturedependent fractionation effect from $\delta^{18} \mathrm{O}_{\mathrm{c}}$ (Shackleton, 1974) should yield a good estimate of the $\delta^{18} \mathrm{O}_{\text {sw }}$ in which the calcite formed. Pioneering studies for estimating time series of $\delta^{18} \mathrm{O}_{\mathrm{sw}}$ using independent measures of temperature include Dwyer et al. (1995), Martin et al. (2002), and Lea et al. (2002). Dwyer et al. (1995) used ostracod Mg/Ca ratios to determine temperature whereas Martin et al. (2002) and Lea et al. (2002) used benthic and planktonic foraminifera, respectively. The $\delta^{18} \mathrm{O}_{\mathrm{c}}$ of benthic foraminifera reflects the temperature and $\delta^{18} \mathrm{O}_{\mathrm{sw}}$ of deep water, while the $\delta^{18} \mathrm{O}_{\mathrm{c}}$ of planktonic foraminifera is affected by sea surface temperature (SST) and the $\delta^{18} \mathrm{O}_{\mathrm{sw}}$ of near-surface water.

\subsection{Benthic $\delta^{18} \mathrm{O}_{\mathrm{sw}}$}

Our analysis includes two benthic $\delta^{18} \mathrm{O}_{\mathrm{sw}}$ records from the North Atlantic and South Pacific, which use the $\mathrm{Mg} / \mathrm{Ca}$ ra- 
tio of benthic foraminifera as a temperature proxy. The South Pacific benthic $\delta^{18} \mathrm{O}_{\mathrm{sw}}$ record (Elderfield et al., 2012) from Ocean Drilling Program (ODP) site $1123\left(171^{\circ} \mathrm{W}, 41^{\circ} \mathrm{S}\right.$; $3290 \mathrm{~m}$ ) reflects the properties of Lower Circumpolar Deep Water, which is a mix of Antarctic Bottom Water (AABW) and North Atlantic Deep Water (NADW). $\mathrm{Mg} / \mathrm{Ca}$ ratios and $\delta^{18} \mathrm{O}_{\mathrm{c}}$ were determined from separate samples of the same species of Uvigerina, which is considered fairly insensitive to the deep water carbonate saturation state (Elderfield et al., 2012). Elderfield et al. (2012) interpolate their data to $1 \mathrm{ka}$ spacing, perform a $5 \mathrm{ka}$ Gaussian smoothing, and convert from $\delta^{18} \mathrm{O}_{\mathrm{sw}}$ to sea level using a factor of $0.01 \% \mathrm{om} \mathrm{m}^{-1}$. Elderfield et al. (2012) report measurement uncertainties for temperature and $\delta^{18} \mathrm{O}_{\mathrm{c}}$ generate a $\delta^{18} \mathrm{O}_{\mathrm{sw}}$ uncertainty of $\pm 0.2 \%$, corresponding to bottom water temperature range of $\pm 1{ }^{\circ} \mathrm{C}$ or about $22 \mathrm{~m}$ of sea level.

The North Atlantic $\delta^{18} \mathrm{O}_{\mathrm{sw}}$ reconstruction is from Deep Sea Drilling Program (DSDP) site $607\left(32^{\circ} \mathrm{W}, 41^{\circ} \mathrm{N}\right.$; $3427 \mathrm{~m}$ ) and nearby piston core Chain 82-24-23PC (Sosdian and Rosenthal, 2009). These sites are bathed by NADW today but were likely influenced by AABW during glacial maxima (Raymo et al., 1990). Mg / Ca was measured using two benthic foraminiferal species, Cibicidoides wuellerstorfi and Oridorsalis umbonatus, which may be affected by changes in carbonate ion saturation state, particularly when deep water temperature drops below $3{ }^{\circ} \mathrm{C}$ (Sosdian and Rosenthal, 2009). The $\delta^{18} \mathrm{O}_{\mathrm{c}}$ data come from a combination of Cibicidoides and Uvigerina species. Sea level was estimated from benthic $\delta^{18} \mathrm{O}_{\mathrm{sw}}$ using a conversion of $0.01 \% \mathrm{~m}^{-1}$ and then taking a three-point running mean. Combining the uncertainties for temperature $\left( \pm 1.1^{\circ} \mathrm{C}\right)$ and $\delta^{18} \mathrm{O}_{\mathrm{c}}( \pm 0.2 \%$ ) reported by Sosdian and Rosenthal (2009) yields a sea level uncertainty of approximately $\pm 20 \mathrm{~m}$ (1 standard error) for the three-point running mean.

\subsection{Planktonic $\delta^{18} \mathrm{O}_{\mathrm{sw}}$}

A 49-core global stack uses the $\delta^{18} \mathrm{O}_{\mathrm{c}}$ from planktonic foraminifera paired with SST proxies from the same core. The planktonic species in this reconstruction were G. ruber, G. bulloides, G. inflata, G. sacculifer, N. dutretriei, and $N$. pachyderma. Forty-four records span the most recent glacial cycle, and seven records extend back to $798 \mathrm{ka}$. Thirty-four records use $\mathrm{Mg} / \mathrm{Ca}$ temperature estimates, and 15 use the alkenone $\mathrm{U}_{37}^{\mathrm{k}^{\prime}}$ temperature proxy. Because $\mathrm{U}_{37}^{\mathrm{k}^{\prime}}$ measurements derive from coccolithophore rather than foraminifera, there is some chance the temperature measured may differ slightly from that affecting $\delta^{18} \mathrm{O}_{\mathrm{c}}$ (Schiebel et al., 2004). However, Shakun et al. (2015) observed no significant differences in $\delta^{18} \mathrm{O}_{\mathrm{sw}}$ estimated from the two SST proxies. An additional concern is that the surface ocean is affected by greater hydrologic variability and characterizes a smaller ocean volume than the deep ocean. Thus, planktonic $\delta^{18} \mathrm{O}_{\text {sw }}$ may differ more from ice volume changes than benthic data. However, these potential disadvantages of us- ing planktonic records may be largely compensated by the use of a global planktonic stack.

The first principal component (stack) of the planktonic records spanning the last glacial cycle represents $71 \%$ of the variance in the records $(n=44)$, suggesting a strong common signal in planktonic $\delta^{18} \mathrm{O}_{\mathrm{sw}}$. However, the $800 \mathrm{ka}$ planktonic $\delta^{18} \mathrm{O}_{\mathrm{sw}}$ stack appears to contain linear trends that differ from other sea level estimates. Therefore, Shakun et al. (2015) corrected their sea level estimate by detrending planktonic $\delta^{18} \mathrm{O}_{\mathrm{sw}}$ based on differences between planktonic and benthic $\delta^{18} \mathrm{O}_{\mathrm{c}}$. Standard errors reported by Shakun et al. (2015) for the $\delta^{18} \mathrm{O}_{\mathrm{sw}}$ stack increase from $0.05 \%$ or the last glacial cycle to $0.12 \%$ at $800 \mathrm{ka}$ due to the reduction in the number of records. The equivalent sea level uncertainties are \pm 6 and $\pm 18 \mathrm{~m}(1 \sigma)$, respectively. All data were interpolated to even $3 \mathrm{ka}$ time intervals.

\subsection{Benthic $\delta^{18} \mathrm{O}_{\mathrm{c}}-$ coral regression}

The sea level reconstruction of Waelbroeck et al. (2002) was developed by fitting polynomial regressions between benthic $\delta^{18} \mathrm{O}_{\mathrm{c}}$ from North Atlantic cores NA 87-22/25 $\left(55^{\circ} \mathrm{N}\right.$, $15^{\circ} \mathrm{W} ; 2161$ and $2320 \mathrm{~m}$ ) and equatorial Pacific core V19$30\left(3^{\circ} \mathrm{S}, 83^{\circ} \mathrm{W} ; 3091 \mathrm{~m}\right)$ to sea level estimates for the last glacial cycle, primarily from corals. Quadratic polynomials were fit during times of ice sheet growth and during the glacial termination in the North Atlantic whereas a linear regression was fit to the Pacific glacial termination. A composite sea level curve was created from the most reliable sections of several cores, primarily from the Pacific. Waelbroeck et al. (2002) interpolated the composite time series to an even $1.5 \mathrm{ka}$ time window and estimated the uncertainty associated with this technique to be $\pm 13 \mathrm{~m}$ of sea level. Transfer functions between benthic $\delta^{18} \mathrm{O}_{\mathrm{c}}$ and coral sea level estimates have also been estimated at lower resolution and applied to 10 different benthic $\delta^{18} \mathrm{O}$ records spanning 0-5 Ma (Siddall et al., 2010; Bates et al., 2014).

\subsection{Inverse ice volume model}

The inverse model of Bintanja et al. (2005) is based on the concept that Northern Hemisphere (NH) subpolar surface air temperature plays a key role in determining both ice sheet size and deepwater temperature, which are the two dominant factors affecting benthic $\delta^{18} \mathrm{O}_{\mathrm{c}}$. A three-dimensional thermomechanical ice sheet model simulates ice sheet $\delta^{18} \mathrm{O}$ content, height, and volume for $\mathrm{NH}$ ice sheets (excluding Greenland) as forced by subpolar air temperature, orbital insolation, and the modern spatial distributions of temperature and precipitation. Antarctic and Greenland ice sheets are assumed to account for $5 \%$ of ocean isotopic change and $15 \%$ of sea level change. Deep water temperature is assumed to scale linearly with the $3 \mathrm{ka}$ mean air temperature. At each time step air temperature is adjusted to maximize agreement between predicted $\delta^{18} \mathrm{O}_{\mathrm{c}}$ and the observed value $0.1 \mathrm{ka}$ later in a 
benthic $\delta^{18} \mathrm{O}_{\mathrm{c}}$ stack (Lisiecki and Raymo, 2005). The model solves for ice volume, temperature, and sea level changes since $1070 \mathrm{ka}$ in $0.1 \mathrm{ka}$ time steps; however, the $\delta^{18} \mathrm{O}_{\mathrm{c}}$ stack used to constrain the model has a resolution of $1-1.5 \mathrm{ka}$. Bintanja et al. (2005) report the uncertainty of their sea level model to be approximately $\pm 12 \mathrm{~m}(1 \sigma)$.

\subsection{Hydraulic control models of semi-isolated basins}

Two sea level reconstructions use hydraulic control models to relate planktonic $\delta^{18} \mathrm{O}_{\mathrm{c}}$ from the Red Sea and Mediterranean Sea to relative sea level. In these semi-isolated basins, $\delta^{18} \mathrm{O}_{\mathrm{sw}}$ is strongly affected by evaporation and exchange with the open ocean as affected by relative sea level at the basin's sill.

Red Sea RSL (Rohling et al., 2009) from 0 to 520 ka is estimated using the $\delta^{18} \mathrm{O}_{\mathrm{c}}$ of planktonic foraminifera from the central Red Sea (GeoTü-KL09). Because extremely saline conditions killed foraminifera during MIS 2 and MIS 12, $\delta^{18} \mathrm{O}_{\mathrm{c}}$ data for these time intervals were estimated by transforming bulk sediment values. Sea level is estimated using a physical circulation model for the Red Sea combined with an oxygen isotope model (Siddall et al., 2004). The physical circulation model simulates exchange flow through the Straits of Bab el Mandeb, which depends strongly on sea level. The current sill depth is $137 \mathrm{~m}$, and its estimated uplift rate is $0.2 \mathrm{~m} \mathrm{ka}^{-1}$. The isotope model assumes steady state with exchange through the sill and evaporation/precipitation. Assumptions of the isotope model include (1) modern evaporation rates and humidity, (2) open ocean $\delta^{18} \mathrm{O}_{\mathrm{sw}}$ scales as $0.01 \% \mathrm{~m}^{-1}$, and (3) SST scales linearly with sea level. A $5{ }^{\circ} \mathrm{C}$ change in SST between Holocene and LGM is used to optimize the model's LGM sea level estimate. Steady-state model solutions for different sea level estimates are used to develop a conversion between $\delta^{18} \mathrm{O}_{\mathrm{c}}$ and sea level, which is approximated as a fifth-order polynomial. Rohling et al. (2009) performed sensitivity tests using plausible ranges of climatic values to produce a $2-\sigma$ uncertainty estimate of $\pm 12 \mathrm{~m}$.

A Mediterranean RSL record (Rohling et al., 2014) is derived from a hydraulic model of flow through the Strait of Gibraltar (Bryden and Kinder, 1991) combined with evaporation and oxygen isotope fractionation equations for the Mediterranean (Siddall et al., 2004). Runoff and precipitation are parameterized based on present-day observations, humidity is assumed constant, and temperature is assumed to covary with sea level. The $\delta^{18} \mathrm{O}_{\mathrm{sw}}$ of Atlantic inflow is scaled using $0.009 \% \mathrm{~m}^{-1}$, and net heat flow through the sill is assumed to be zero. The combined models yield a converter between $\delta^{18} \mathrm{O}_{\mathrm{c}}$ and sea level, which is approximated as a polynomial. This polynomial conversion is applied to an eastern Mediterranean planktonic $\delta^{18} \mathrm{O}_{\mathrm{c}}$ stack (Wang et al., 2010) after identification and removal of sapropel layers. Model uncertainty is evaluated using random parameter variations, which yield $95 \%$ confidence intervals of $\pm 20 \mathrm{~m}$ for individual $\delta^{18} \mathrm{O}_{\mathrm{c}}$ values. By performing a probabilistic assessment of the final sea level reconstruction with $1 \mathrm{ka}$ time steps, Rohling et al. (2014) estimate that these uncertainties are reduced to $\pm 6.3 \mathrm{~m}$. Additionally, the authors propose that RSL at this location is linearly proportional to eustatic sea level.

\section{Methods}

\subsection{Record inclusion criteria}

The criteria for record inclusion in our stack were availability, a temporal resolution of at least $5 \mathrm{ka}$, and a length of at least $430 \mathrm{ka}$. The five records which extended to $798 \mathrm{ka}$ were also included in a longer stack. Some available records were too short for inclusion (e.g., Dwyer et al., 1995; Martin et al., 2002; Lea et al., 2002). The record of Siddall et al. (2010) was not included because it was based on the same technique as Waelbroeck et al. (2002) but with lower resolution. Bates et al. (2014) extended this technique to many benthic $\delta^{18} \mathrm{O}$ records but advocated against placing them all on a common age model; therefore, we include a summary of that study's lowstand and highstand estimates in Table 2 rather than aligning them for inclusion in the stack.

\subsection{Age models}

To create an average (or stack) of sea level records, all of the time series must be placed on a common age model (Fig. 1). Here we use the age model of the orbitally tuned "LR04" benthic $\delta^{18} \mathrm{O}_{\mathrm{c}}$ stack (Lisiecki and Raymo, 2005), which has an uncertainty of $4 \mathrm{ka}$ in the Late Pleistocene. An age model for the Red Sea reconstruction based on correlation to speleothems is generally similar to LR04 with smaller age uncertainty but only extends to $500 \mathrm{ka}$ (Grant et al., 2014) and, thus, does not provide an age framework for the entire 798 ka stack. Due to age model uncertainty, our interpretation focuses on the amplitude of sea level variability rather than its precise timing.

We do not assume that sea level varies synchronously with benthic $\delta^{18} \mathrm{O}_{\mathrm{c}}$. Age models for three of the reconstructions are based on aligning individual $\delta^{18} \mathrm{O}_{\mathrm{c}}$ records to the LR04 $\delta^{18} \mathrm{O}_{\mathrm{c}}$ stack, and one reconstruction (Bintanja et al., 2005) was derived directly from the LR04 stack. The other three sea level reconstructions were dated by aligning their sea level estimates to a preliminary stack of the four sea level records that were dated using $\delta^{18} \mathrm{O}_{\mathrm{c}}$ alignments. Alignments were performed using the Match graphic correlation software package (Lisiecki and Lisiecki, 2002).

The three records which use $\delta^{18} \mathrm{O}_{\mathrm{c}}$ alignments to the LR04 stack are site 607 , site 1123 , and the planktonic $\delta^{18} \mathrm{O}_{\mathrm{sw}}$ stack. For site 607 we perform our own alignment of benthic $\delta^{18} \mathrm{O}_{\mathrm{c}}$ to the LR04 stack, whereas for the other two we use the same age models published by Elderfield et al. (2012) and Shakun et al. (2015). One potential concern about aligning benthic 


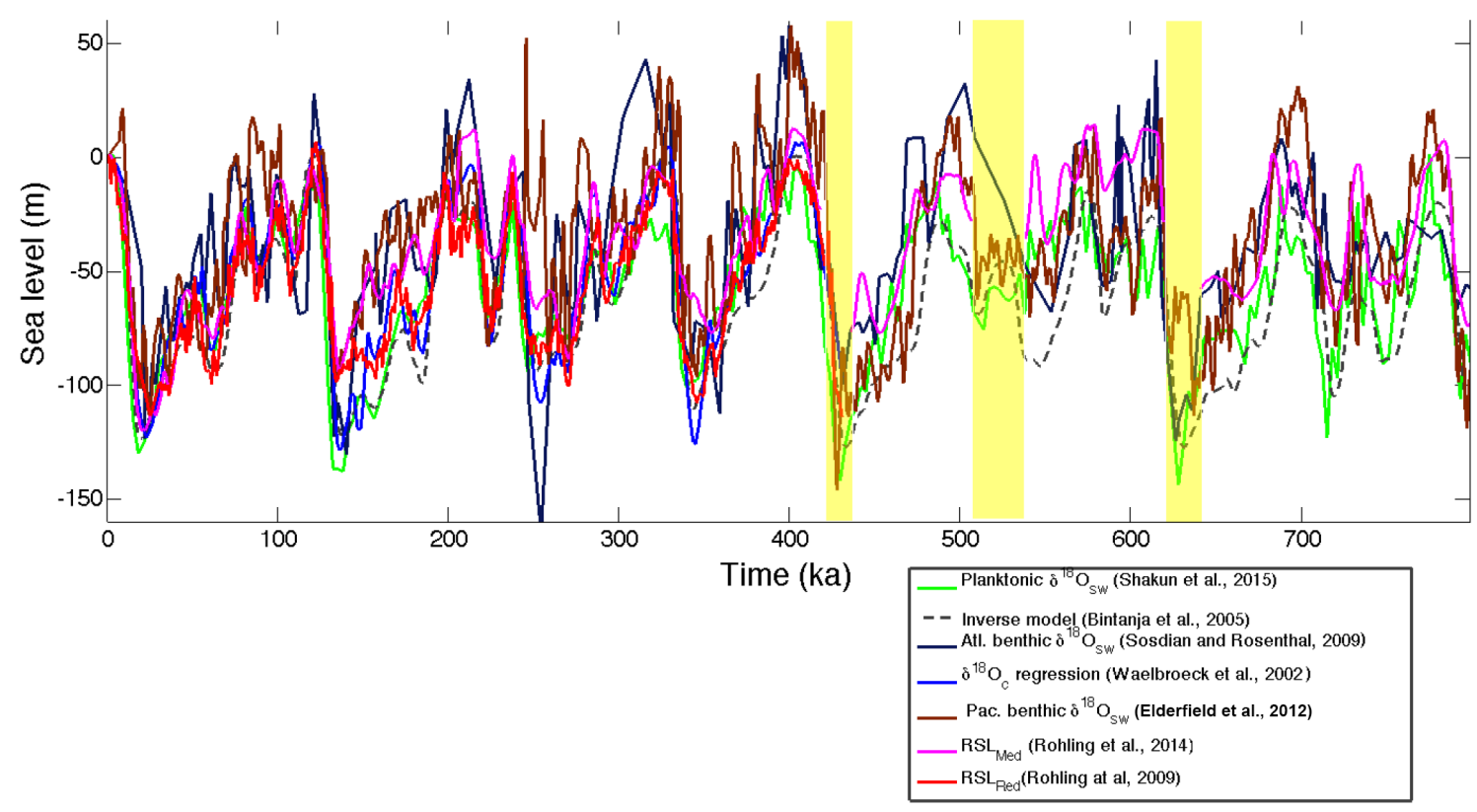

Figure 1. Eustatic and relative sea level estimates for the seven records on the LR04 age model (Lisiecki and Raymo, 2005). Yellow bars mark the sapropel layers removed from the Mediterranean RSL record (Rohling et al., 2014).

$\delta^{18} \mathrm{O}_{\mathrm{c}}$ records is that the timing of benthic $\delta^{18} \mathrm{O}_{\mathrm{c}}$ change at different sites may differ by as much as $4 \mathrm{kyr}$ during glacial terminations (Skinner and Shackleton, 2005; Lisiecki and Raymo, 2009; Stern and Lisiecki, 2014). The potential effects of lags in benthic $\delta^{18} \mathrm{O}_{\mathrm{c}}$ are evaluated using bootstrap uncertainty analysis (Sect. 4.2).

For three reconstructions (Waelbroeck et al., 2002; Rohling et al., 2009, 2014) we aligned the individual sea level records with a preliminary sea level stack based on the other four sea level records on the LR04 age model. This was necessary because the local $\delta^{18} \mathrm{O}_{\mathrm{c}}$ signals in semi-isolated basins (Rohling et al., 2009, 2014) differ substantially from global mean benthic $\delta^{18} \mathrm{O}_{\mathrm{c}}$. In the coral-regression reconstruction, Waelbroeck et al. (2002) pasted together portions of individual cores to form a preferred global composite. Although each core has benthic $\delta^{18} \mathrm{O}_{\mathrm{c}}$ data, generating new age estimates for these cores could alter their $\delta^{18} \mathrm{O}_{\mathrm{c}}$ regression functions or create gaps or inconsistencies in the composite. The procedure of aligning these three sea level records (Waelbroeck et al., 2002; Rohling et al., 2009, 2014) to a preliminary sea level stack should be approximately as accurate as the $\delta^{18} \mathrm{O}_{\mathrm{c}}$ alignments. However, the direct sea level alignments do have a slightly greater potential to align noise or local sea level variability.

After age models were adjusted, five of the records ended within the Holocene. Therefore, we appended a value of $0 \mathrm{~m}$ (i.e., present-day sea level) at $0 \mathrm{ka}$. In the two records which did end at $0 \mathrm{ka}$, modern sea level estimates were slightly below zero: $-1.5 \mathrm{~m}$ (Bintanja et al., 2005) and $-1.3 \mathrm{~m}$ (Rohling et al., 2014).

\subsection{Principal component analysis}

Principal component analysis (PCA) is commonly used to create stacks of paleoclimate data (e.g., Huybers and Wunsch, 2004; Clark et al., 2012; Gibbons et al., 2014) and to quantify the common signal contained in core data. Synthesis is valuable because each record has its own assumptions and errors. If these records are all well-constrained measures of sea level, then PCA will reveal their respective levels of agreement or discrepancy. Additionally, PCA does not require the assumption that each sea level record represents an independent measure of common signal. In contrast, a sea level estimate based on the unweighted mean of records would imply that uncertainties are uncorrelated across individual reconstructions. While all records contain a strong ice volume signal, some of the non-ice volume signals are expected to correlate with one another. For example, as the $\delta^{18} \mathrm{O}$ of ice sheet changes as it melts or freezes, the conversion from the $\delta^{18} \mathrm{O}_{\text {sw }}$ to ice volume will be systematically biased, whereas changes in the hydrological cycle may induce changes in the spatial variability of $\delta^{18} \mathrm{O}_{\mathrm{sw}}$ at different locations in the ocean.

We include both relative and eustatic sea level estimates in the analysis because PCA should identify the common variance that dominates both relative and eustatic sea level records. Three records are proxies for relative sea level at their respective locations: the strait of Gibraltar (Rohling et al., 2014), the Straits of Bab el Mandeb (Rohling et al., 2009), and tropical coral terraces (Waelbroeck et al., 2002). The inverse model generates eustatic sea level from a modeled ice volume estimate (Bintanja et al., 2005), 
Table 1. Principal component analysis (PCA) loading for each proxy record. "Short" refers to the 0-430 ka time window, and "Long" refers to $0-798 \mathrm{ka}$. Numbers in parentheses give the percent variance explained by each principal component.

\begin{tabular}{|c|c|c|c|c|c|c|}
\hline & \multicolumn{2}{|c|}{$\mathrm{PC} 1$} & \multicolumn{2}{|c|}{ PC2 } & \multicolumn{2}{|c|}{ PC3 } \\
\hline & $\begin{array}{l}\text { Short } \\
(83 \%)\end{array}$ & $\begin{array}{c}\text { Long } \\
(77 \%)\end{array}$ & $\begin{array}{l}\text { Short } \\
(6 \%)\end{array}$ & $\begin{array}{l}\text { Long } \\
(8 \%)\end{array}$ & $\begin{array}{l}\text { Short } \\
(5 \%)\end{array}$ & $\begin{array}{l}\text { Long } \\
(6 \%)\end{array}$ \\
\hline Inverse model (Bintanja et al., 2005) & 0.4 & 0.48 & -0.0 & -0.11 & -0.16 & 0.02 \\
\hline Pacific benthic $\delta^{18} \mathrm{O}_{\mathrm{sw}}$ (Elderfield et al., 2012) & 0.34 & 0.44 & -0.7 & -0.5 & 0.52 & 0.67 \\
\hline Planktonic $\delta^{18} \mathrm{O}_{\mathrm{sw}}$ (Shakun et al., 2015) & 0.37 & 0.45 & -0.01 & -0.19 & -0.65 & -0.65 \\
\hline RSL $_{\text {Med }}$ (Rohling et al., 2014) & 0.38 & 0.45 & 0 & 0.01 & 0.04 & -0.27 \\
\hline Atlantic benthic $\delta^{18} \mathrm{O}_{\mathrm{sw}}$ (Sosdian and Rosenthal, 2009) & 0.35 & 0.42 & 0.7 & 0.84 & 0.51 & 0.26 \\
\hline$\delta^{18} \mathrm{O}_{\mathrm{c}}$ regression (Waelbroeck et al., 2002) & 0.4 & - & 0.08 & - & -0.11 & - \\
\hline RSL Red $_{\text {Rohling et al., 2009) }}$ & 0.4 & - & -0.01 & - & -0.07 & - \\
\hline
\end{tabular}

and the three $\delta^{18} \mathrm{O}_{\mathrm{sw}}$ records (Elderfield et al., 2012; Sosdian and Rosenthal, 2009; Shakun et al., 2015) were scaled to eustatic sea level. However, for the planktonic stack we use the $\delta^{18} \mathrm{O}_{\mathrm{sw}}$ record rather than the eustatic sea level conversion because the sea level conversion involved detrending to make planktonic $\delta^{18} \mathrm{O}_{\mathrm{c}}$ values agree with benthic $\delta^{18} \mathrm{O}_{\mathrm{c}}$. Because PCA is designed to identify the common variance between the sea level proxies, it is preferable to keep the planktonic and benthic $\delta^{18} \mathrm{O}_{\mathrm{sw}}$ records independent of one another.

In the Mediterranean RSL record we removed putative sapropel layers at 434-452, 543-558, and 630-663 ka as visually identified by Rohling et al. (2014). Because interpolating linearly across these gaps (Fig. 1) would bias sea level estimates towards higher lowstands for the glacial maxima occurring during these sapropel layers, we assumed that sea level remained constant at its pre-sapropel (glacial) level and then immediately jumped to the higher sea level values observed the ends of the sapropel layers (midway through the glacial terminations). Although this solution is not ideal, we must assume some sea level value at these times in order to include this record in the PCA.

Before PCA all seven records were interpolated to an even $1 \mathrm{ka}$ time step. Then, to ensure equal weighting for each record in the PCA, each time series was normalized to a mean of zero and a standard deviation of one within each of the two time windows ( $0-430$ and $0-798 \mathrm{ka})$. PCA was performed on seven records from 0 to $430 \mathrm{ka}$ and five records from 0 to $798 \mathrm{ka}$ (Fig. 2). Because PC1 produces similar loadings for each record (Table 1), the PC1 scores approximate the average of all records for each point in time, which we refer to as a sea level stack.

We scaled the short and long stacks to eustatic sea level using an LGM value of $-130 \mathrm{~m}$ at $24 \mathrm{ka}$ based on a GIA-corrected coral compilation (Clark et al., 2009) and a Holocene value of $0 \mathrm{~m}$ at $5 \mathrm{ka}$. We scale the Holocene at $5 \mathrm{ka}$ because eustatic sea level has been essentially constant for the past $5 \mathrm{ka}$ (Clark et al., 2009), whereas the sea level stacks display a trend throughout the Holocene perhaps due to bioturbation in the sediment cores. Scaling the sea level stack based on the mid-Holocene (rather than $0 \mathrm{ka}$ ) should more accurately correct for the effects of bioturbation on previous interglacials because those highstand values have been subjected to mixing from both above and below. Finally, a composite sea level stack was created by joining the $0-430 \mathrm{ka}$ stack with the 431-798 ka portion of the long stack after each was scaled to sea level. Because the two scaled sea level stacks produce similar values for 0-430 ka (Fig. 2), no correction was needed to combine the records.

\section{Uncertainty analysis}

Because each of the records in the PCA is a sea level proxy and PC1 describes the majority of variance in the records, PC1 should represent the underlying common eustatic sea level signal in all proxies. $\mathrm{PC} 1$ describes $82 \%$ of the variance in the seven records from 0 to $430 \mathrm{ka}$ and $76 \%$ of proxy variance from 0 to $798 \mathrm{ka}$. Where the two time windows overlap (Fig. 2), the scaled sea level stacks have a root mean square error of only $3.4 \mathrm{~m}$, thereby suggesting that the long stack is nearly as accurate as the short stack although it contains two fewer records. We assess the uncertainty of the scaled PC1 using multiple techniques: comparison with highstand and lowstand estimates from individual records (Sect. 4.1), comparison with the unweighted mean of all records (Sect. 4.1), and use of bootstrapping and Monte Carlo-style random sampling (Sect. 4.2).

\subsection{Mean sea level estimates}

To test the effectiveness of using the scaled PC1 as a record of mean sea level, we compared our stack with highstand and lowstand values identified from individual records and with coral-based estimates where available (Tables 2, 3). We picked the relevant highstand or lowstand for each individual record by choosing the peak that lies within the age range of each Marine Isotope Stage (MIS) as identified in the sea level stack. Highstand or lowstand peaks which occurred outside of the age range of each particular glacial or interglacial stage 

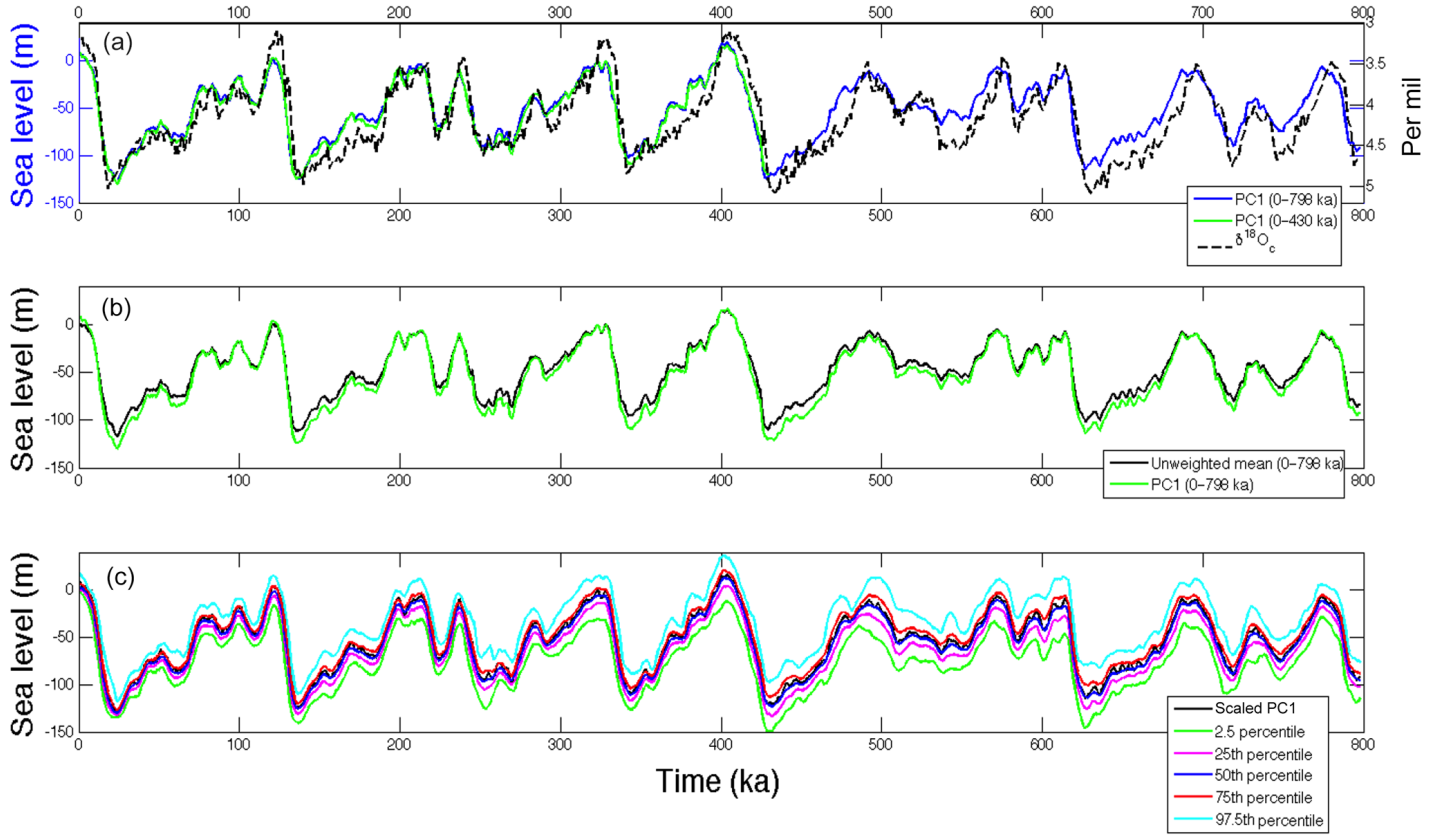

Figure 2. (a) Long and short sea level stacks compared to the LR04 benthic $\delta^{18} \mathrm{O}_{\mathrm{c}}$ stack (Lisiecki and Raymo, 2005). (b) Scaled PC1 compared to unweighted mean of individual records. Scaled PC1 is comprised of short PC1 (0-431 ka) pasted to long PC1 (431-798 ka). (c) Scaled PC1 compared with percentile levels from the bootstrap results, which are also plotted as a composite of the short (0-431 ka) and long (431-798 ka) time windows.

were not used (e.g., extreme values at $\sim 250 \mathrm{ka}$ from ODP sites 1123 and 607).

Highstand sea level estimates vary widely between individual records with standard deviations of 11-26 m for each isotopic stage (Table 3). For example, individual estimates for MIS 11 at $\sim 400 \mathrm{ka}$ vary between -5 and $57 \mathrm{~m}$ above modern, with a mean of $18 \mathrm{~m}$ and a standard deviation of $25 \mathrm{~m}$. MIS 5e (119-126 ka) estimates range from -4 to $28 \mathrm{~m}$ above modern with a mean of $7 \mathrm{~m}$ and a standard deviation of $12 \mathrm{~m}$. Generally, the highstand means have slightly greater amplitudes than our scaled stack; for example, the scaled stack estimates are 18 and $7 \mathrm{~m}$ for MIS 11 and MIS 5e, respectively. On the other hand, the mean of individual lowstands for the LGM $(-123 \mathrm{~m})$ underestimates eustatic sea level change, which is estimated to be -130 to $-134 \mathrm{~m}$ (Clark et al., 2009; Lambeck et al., 2014).

The means of the individually picked highstands may be biased by the additive effects of noise. Conversely, the stack may underestimate sea level highstands if the individual age models are not properly aligned. The most definitive sea level estimates come from GIA-corrected coral compilations, which yield highstand estimates of 6-13 $\mathrm{m}$ above modern for MIS 11 (Raymo and Mitrovica, 2012) and 8-9.4 $\mathrm{m}$ for MIS 5e (Kopp et al., 2009). These values suggest that the stack may be more accurate for MIS 11 than MIS 5e, potentially because age model uncertainty would have less effect on the longer MIS 11 highstand. In contrast, MIS 5e may have consisted of two highstands each lasting only $\sim 2 \mathrm{ka}$ separated by several thousand years with sea level at or below modern (Kopp et al., 2013). Thus, the stack's highstand estimates likely fail to capture short-term sea level fluctuations but rather reflect mean sea level during each interglacial.

To further test the sensitivity of our method, we compared the scaled PC1 with the unweighted mean of the seven interpolated sea level records (Fig. 2b). The unweighted-mean stack incorporates the same data as scaled PC1 except that it excludes Mediterranean estimates from sapropel intervals and uses the detrended sea level estimates from Shakun et al. (2015) instead of the raw $\delta^{18} \mathrm{O}_{\mathrm{sw}}$ data. The unweighted stack closely resembles $\mathrm{PC} 1$ because the loadings of $\mathrm{PC} 1$ are very similar for all seven records (Table 1). However, the unweighted stack underestimates LGM sea level, possibly because some records (e.g., Rohling et al., 2009) may contain brief gaps at the glacial maximum. Thus, we prefer to scale PC1 to agree with well-constrained LGM sea level estimates. The scaled PC1 is in better agreement with the glacial sea level estimates of the unweighted five-record stack from 430 to $798 \mathrm{ka}$.

\subsection{Bootstrapping and random sampling}

We estimate uncertainty in the stack using a bootstrap technique instead of using the published uncertainty estimates for each sea level reconstruction, which are based on different assumptions and techniques and do not necessarily include all sources of uncertainty (e.g., uncertainty in benthic 
Table 2. Sea level highstand and lowstand estimates from individual records (in meters above modern). See Table 1 for references. The last column gives the mean values from nine cores in Bates et al. (2014); these estimates were not included in our PCA.

\begin{tabular}{|c|c|c|c|c|c|c|c|c|c|}
\hline $\begin{array}{l}\text { Marine } \\
\text { Isotope } \\
\text { Stage }\end{array}$ & $\begin{array}{l}\text { Age } \\
(\mathrm{ka})\end{array}$ & $\begin{array}{r}\text { Inverse } \\
\text { model }\end{array}$ & $\begin{array}{l}\text { Pacific } \\
\text { benthic } \\
\delta^{18} \mathrm{O}_{\mathrm{sw}}\end{array}$ & $\mathrm{RSL}_{\mathrm{Red}}$ & $\mathrm{RSL}_{\mathrm{Med}}$ & $\begin{array}{l}\text { Planktonic } \\
\delta^{18} \mathrm{O}_{\mathrm{sw}}\end{array}$ & $\begin{array}{l}\text { Atlantic } \\
\text { benthic } \\
\delta^{18} \mathrm{O}_{\mathrm{sw}}\end{array}$ & $\begin{array}{r}\delta^{18} \mathrm{O}_{\mathrm{c}} \\
\text { regression }\end{array}$ & $\begin{array}{r}\text { Bates et } \\
\text { al. (2014) } \\
\text { mean }\end{array}$ \\
\hline 2 & $18-25$ & -123 & -113 & -114 & -120 & -130 & -124 & -123 & -133 \\
\hline $5 e$ & 119-126 & 0 & 3 & 18 & -4 & -10 & 28 & 4.9 & 12 \\
\hline 6 & $135-141$ & -123 & -130 & -99 & -94 & -138 & -97 & -129 & -130 \\
\hline $7 a-c$ & $197-214$ & -20 & 12 & 14 & 12 & -16 & 34 & -3.6 & -3 \\
\hline $7 \mathrm{e}$ & $236-255$ & -18 & 16 & -3 & 1 & -20 & -6.2 & -9.4 & -10 \\
\hline 9 & $315-331$ & -0.5 & 40 & 11 & -5 & -27 & 43 & 5 & 8 \\
\hline 10 & $342-353$ & -111 & -96 & -114 & -77 & -98 & -112 & -126 & -122 \\
\hline 11 & 399-408 & 0 & 58 & 4 & 12 & -5 & 57 & 5.7 & 9 \\
\hline 12 & $427-458$ & -126 & -146 & -118 & - & -142 & -100 & - & -147 \\
\hline 13 & $486-502$ & -29 & 18 & - & -8 & -11 & 32 & - & -5 \\
\hline 16 & $625-636$ & -126 & -113 & - & - & -144 & -125 & - & -141 \\
\hline 17 & $682-697$ & -23 & 31 & - & 0.5 & -12 & 8.1 & - & -4 \\
\hline 19 & $761-782$ & -21 & 21 & - & 7.2 & 1 & -6.8 & - & -2 \\
\hline
\end{tabular}

Table 3. Mean and standard deviation of sea level highstand and lowstand estimates (in meters above modern) from Table 2 compared to scaled PC1 and GIA-corrected estimates from corals and other coastal proxies. GIA-corrected estimates for MIS 2 are from Clark et al. (2009) and Lambeck et al. (2014), for MIS 5e from Dutton et al. (2015), and for MIS 11 from Raymo and Mitrovica (2012). Bootstrap $95 \%$ confidence intervals are from sampling the seven-record-short PC1 for MIS 2-11 and from the five-record-long PC1 for MIS 12-19.

\begin{tabular}{llcrcrrl}
\hline $\begin{array}{l}\text { Marine Isotope } \\
\text { Stage }\end{array}$ & $\begin{array}{l}\text { Age range } \\
(\mathrm{ka})\end{array}$ & $\begin{array}{l}\text { Standard } \\
\text { deviation }\end{array}$ & Mean & $\begin{array}{c}\text { GIA- } \\
\text { corrected }\end{array}$ & $\begin{array}{r}\text { Scaled PC1 } \\
(0-430 \mathrm{ka})\end{array}$ & $\begin{array}{c}\text { Scaled PC1 } \\
(0-798 \mathrm{ka})\end{array}$ & $\begin{array}{l}\text { Bootstrap } \\
95 \% \text { confidence interval }\end{array}$ \\
\hline 2 & $18-25$ & 7 & -123 & -130 to -134 & -130 & -130 & -136 to -128 \\
$5 \mathrm{e}$ & $119-126$ & 12 & 7 & 6 to 9 & -12 & -1 & -14 to 17 \\
6 & $135-141$ & 18 & -118 & - & -123 & -125 & -142 to -111 \\
$7 \mathrm{a}-\mathrm{c}$ & $197-214$ & 18 & 4 & - & -7 & -5 & -25 to 14 \\
$7 \mathrm{e}$ & $236-255$ & 11 & -6 & - & -9 & -13 & -32 to -1 \\
9 & $315-331$ & 23 & 9 & - & -1 & -2 & -27 to 20 \\
10 & $342-353$ & 16 & -107 & - & 16 & -103 & -128 to -92 \\
11 & $399-408$ & 25 & 18 & 6 to & - & -13 & -11 to 40 \\
12 & $427-458$ & 19 & -130 & - & - & -124 & -163 to -100 \\
13 & $486-502$ & 22 & -1 & - & -35 to 16 \\
16 & $625-636$ & 13 & -130 & - & - & -115 & -149 to -87 \\
17 & $682-697$ & 19 & 0 & - & - & -28 to 15 \\
19 & $761-782$ & 14 & 0 & - & -6 & -25 to 10 \\
\hline
\end{tabular}

$\delta^{18} \mathrm{O}_{\mathrm{c}}$ alignments). We ran 1000 bootstrap iterations while also performing random sampling to account for several of the uncertainties associated with our method. Before each iteration of the bootstrapped PCA, we simulate the effects of uncertainty associated with our age model alignments by applying an independent age shift of $-2,-1,0,+1$, or $+2 \mathrm{ka}$ to each component record, with each potential value selected with equal probability. After performing each iteration of the PCA, we use random sampling to evaluate the effects of uncertainty associated with scaling PC1 to Holocene and LGM sea level. The particular Holocene point scaled to $0 \mathrm{~m}$ is randomly sampled from 0 to $6 \mathrm{ka}$ with uniform distribution. The LGM age is identified as the minimum sea level estimate between 19 and $34 \mathrm{ka}$, and the sea level to which it is scaled is sampled with a normal distribution centered at $132 \mathrm{~m}$ with a standard deviation of $2 \mathrm{~m}$. The bootstrap results for the scaled PC1 yield a mean standard deviation of $9.4 \mathrm{~m}$ with seven records $(0-430 \mathrm{ka})$ and $12 \mathrm{~m}$ with five records $(0-$ $798 \mathrm{ka}$ ). Additionally, the inclusion of age uncertainty in the bootstrap analysis has the effect of systematically smoothing the record. Because many of the individual reconstructions are of low resolution relative to brief interglacial highstands such as MIS 5e and 7e, the bootstrapped median is biased towards underestimating these highstands (Fig. 2c). Therefore, in Table 3 we additionally describe the $95 \%$ confidence in- 
terval for sea level maxima and minima in the bootstrapped samples.

\section{The sea level contribution to benthic $\delta^{18} \mathrm{O}_{\mathrm{c}}$}

The sea level stack and the LR04 benthic $\delta^{18} \mathrm{O}_{\mathrm{c}}$ stack are strongly correlated $(r=-0.90)$. However, because $\delta^{18} \mathrm{O}_{\mathrm{c}}$ contains both an ice volume and temperature component, the $\delta^{18} \mathrm{O}_{\mathrm{c}}$ record has a greater amplitude than the ice volumedriven $\delta^{18} \mathrm{O}_{\mathrm{sw}}$ record. The spectral variance of $\delta^{18} \mathrm{O}_{\mathrm{sw}}$ and $\delta^{18} \mathrm{O}_{\mathrm{c}}$ in each orbital band can be used to determine the relative contributions of sea level and temperature variability in $\delta^{18} \mathrm{O}_{\mathrm{c}}$. For this comparison, we convert the sea level stack to $\delta^{18} \mathrm{O}_{\text {sw }}$ using $0.009 \% o \mathrm{~m}^{-1}$.

Although some studies have used $0.01 \%$ o $\mathrm{m}^{-1}$ (e.g., Sosdian et al., 2009; Elderfield et al., 2012; Rohling et al., 2009), this conversion factor is likely too high for global mean $\delta^{18} \mathrm{O}_{\text {sw }}$ change at the LGM. Several lines of evidence suggest an LGM $\delta^{18} \mathrm{O}_{\mathrm{sw}}$ change of $1-1.1 \%$ (Duplessy et al., 2002; Adkins et al., 2002; Elderfield et al., 2012; Shakun et al., 2015), while LGM sea level was likely $125-134 \mathrm{~m}$ below modern (Clark et al., 2009; Lambeck et al., 2014; Rohling et al., 2014). These estimates suggest a conversion factor between 0.008 and $0.009 \% \mathrm{~m}^{-1}$. A conversion of $0.008 \% \mathrm{~m}^{-1}$ would be consistent with a $\delta^{18} \mathrm{O}_{\text {ice }}$ of $-32 \%$ o (Elderfield et al., 2012), similar to estimates for the Laurentide and Eurasian ice sheets (Duplessy et al., 2002; Bintanja et al., 2005; Elderfield et al., 2012). Therefore, $0.009 \% \mathrm{~m}^{-1}$ may be more appropriate when also considering changes in Greenland and Antarctic ice. However, the conversion factor between sea level and mean $\delta^{18} \mathrm{O}_{\mathrm{sw}}$ also likely varies through time as a result of changes in the mean isotopic content of each ice sheet (Bintanja et al., 2005) and their relative sizes.

Spectral analysis shows strong 100 and 41 ka peaks in both the LR0 4 benthic $\delta^{18} \mathrm{O}_{\mathrm{c}}$ stack and the sea level stack (Fig. 3). When converted to $\delta^{18} \mathrm{O}_{\text {sw }}$, the sea level stack contains $47 \%$ as much $100 \mathrm{ka}$ power $\left(0.009-0.013 \mathrm{ka}^{-1}\right.$ frequency band) as benthic $\delta^{18} \mathrm{O}_{\mathrm{c}}$ and $37 \%$ as much $41 \mathrm{ka}$ power $(0.024$ $\left.0.026 \mathrm{ka}^{-1}\right)$. The bootstrapped PC1 samples described in Sect. 4.2 are used to estimate $95 \%$ confidence intervals (CIs) of 31-65 and 22-54\% for the relative power of $\delta^{18} \mathrm{O}_{\mathrm{sw}}$ in the 100 and 41 ka bands, respectively. Considering all frequencies less than $0.1 \mathrm{ka}^{-1}, \delta^{18} \mathrm{O}_{\mathrm{sw}}$ explains $44 \%(95 \% \mathrm{CI}=33-$ $57 \%$ ) of the variance in $\delta^{18} \mathrm{O}_{\mathrm{c}}$. Therefore, we estimate that on average about $45 \%$ of the glacial cycle variance in benthic $\delta^{18} \mathrm{O}_{\mathrm{c}}$ derives from ice volume change and $55 \%$ from deep sea temperature change.

This $\sim 45 \%$ ice volume contribution to benthic $\delta^{18} \mathrm{O}_{\mathrm{c}}$ is smaller than the contribution estimated across the LGM to Holocene transition. An LGM sea level change of $130 \mathrm{~m}$ (Clark et al., 2009) should shift mean $\delta^{18} \mathrm{O}_{\mathrm{sw}}$ by $1.17 \%$, whereas benthic $\delta^{18} \mathrm{O}_{\mathrm{c}}$ changed by $1.79 \%$ (Lisiecki and Raymo, 2005), suggesting that $65 \%$ of the LGM $\delta^{18} \mathrm{O}_{\mathrm{c}}$ change was driven by ice volume. Many other studies have

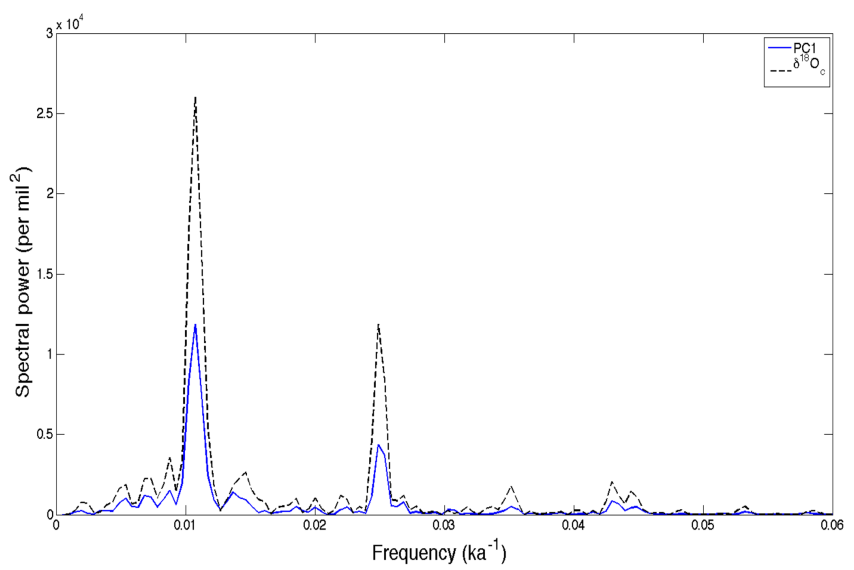

Figure 3. Spectral analysis for composite sea level stack (scaled PC1) converted to its $\delta^{18} \mathrm{O}_{\mathrm{sw}}$ contribution using $0.009 \% \mathrm{~m}^{-1}$ and benthic $\delta^{18} \mathrm{O}_{\mathrm{c}}$ stack (Lisiecki and Raymo, 2005) from 0 to $798 \mathrm{ka}$.

similarly found that the ice volume $\left(\delta^{18} \mathrm{O}_{\mathrm{sw}}\right)$ contribution to $\delta^{18} \mathrm{O}_{\mathrm{c}}$ is greatest during glacial maxima (Bintanja et al., 2005; Elderfield et al., 2012; Rohling et al., 2014; Shakun et al., 2015). Additionally, the $\delta^{18} \mathrm{O}_{\mathrm{sw}}$ contribution varies by location, ranging from 0.7 to $1.37 \%$ based on glacial pore water reconstructions (Adkins et al., 2002). The wide variability in $\delta^{18} \mathrm{O}_{\mathrm{sw}}$ between sites suggests that changes in deep water formation processes (e.g., evaporation versus brine rejection) greatly affect the $\delta^{18} \mathrm{O}_{\mathrm{sw}}$ signal regionally or locally. Therefore, the $\delta^{18} \mathrm{O}_{\mathrm{sw}}$ at a single site may differ considerably from eustatic sea level.

\section{Converting from benthic $\delta^{18} \mathrm{O}_{\mathrm{c}}$ and sea level}

Many studies have used benthic $\delta^{18} \mathrm{O}_{\mathrm{c}}$ as a proxy for ice volume based on the argument that temperature and ice volume should be highly correlated through time (e.g., Imbrie and Imbrie, 1980; Abe-Ouchi et al., 2013). However, calculations based on the sea level stack spectral power and LGM-toHolocene change suggest that ice volume change accounts for only $45-65 \%$ of benthic $\delta^{18} \mathrm{O}_{\mathrm{c}}$ glacial cyclicity Additionally, over the course of a glacial cycle the relative contributions of ice volume and temperature change dramatically, with temperature change preceding ice volume change (Bintanja et al., 2005; Elderfield et al., 2012; Shakun et al., 2015). Despite these complications the LR04 benthic $\delta^{18} \mathrm{O}_{\mathrm{c}}$ stack is strongly correlated with the sea level stack $(r=-0.9)$. Here we explore more closely the functional relationship between benthic $\delta^{18} \mathrm{O}_{\mathrm{c}}$ and sea level as inspired by Waelbroeck et al. (2002).

Waelbroeck et al. (2002) solved for regression functions between several benthic $\delta^{18} \mathrm{O}_{\mathrm{c}}$ records and coral elevation data over the last glacial cycle and found different functional forms for glaciation versus deglaciation and for the North Atlantic versus equatorial Pacific $\delta^{18} \mathrm{O}_{\mathrm{c}}$. Here we compare the 

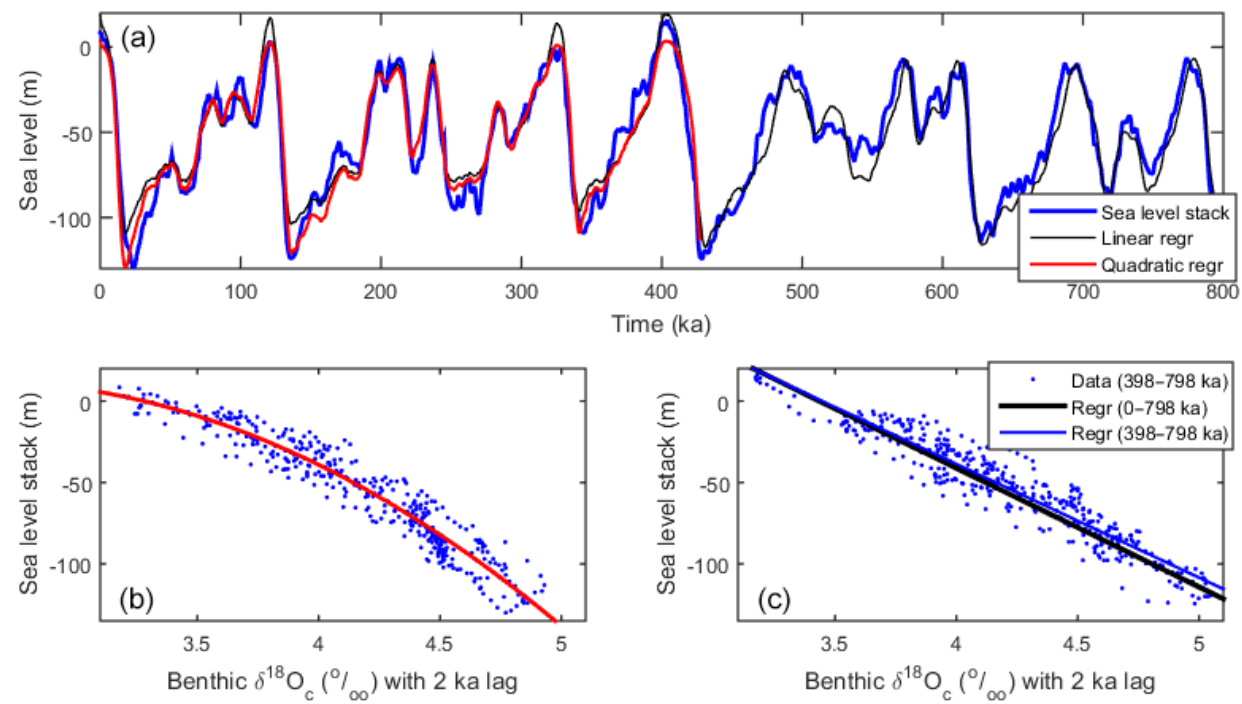

Figure 4. Comparison of benthic $\delta^{18} \mathrm{O}_{\mathrm{c}}$ and sea level. (a) Linear and quadratic sea level models (Eqs. 1, 2, respectively) using smoothed benthic $\delta^{18} \mathrm{O}_{\mathrm{c}}$ (Lisiecki and Raymo, 2005) lagged by $2 \mathrm{ka}$. (b) Data from 0 to $397 \mathrm{ka}$ with quadratic regression (red line). (c) Data from 398 to $798 \mathrm{ka}$ with linear regression for 0-798 ka (black line) and 398-798 ka (blue line).
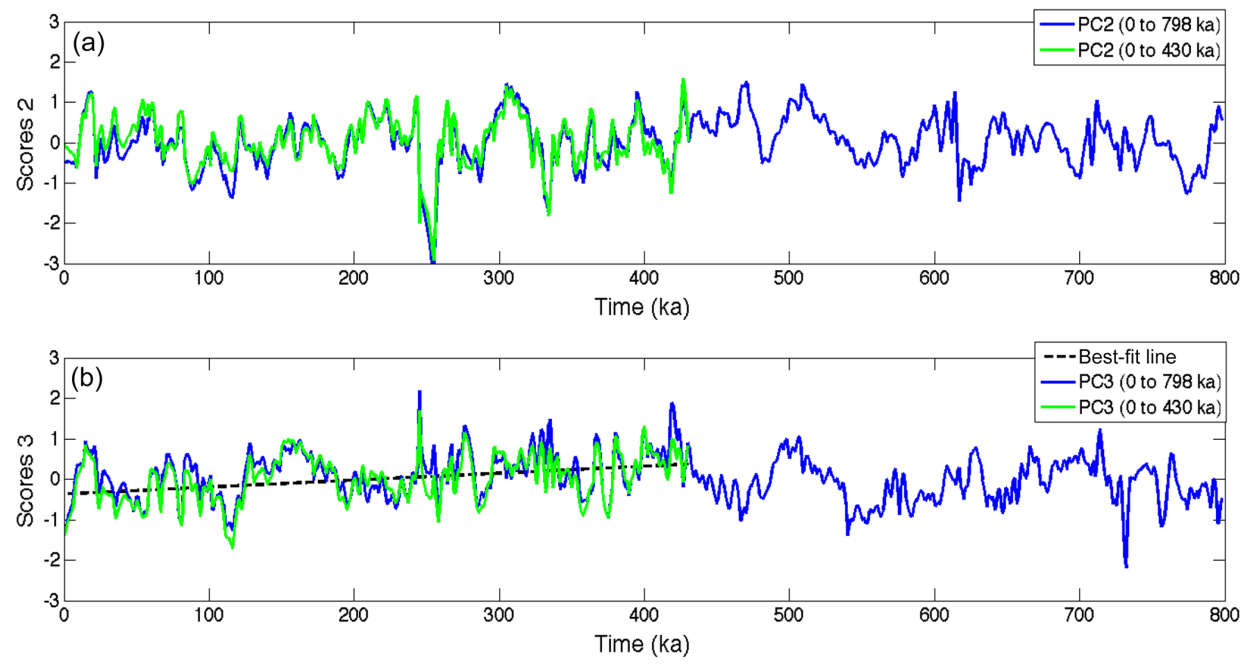

Figure 5. Second and third principal components for 0-430 and 0-798 ka. (a) Scores for PC2 largely reflect the difference between Atlantic and Pacific benthic $\delta^{18} \mathrm{O}_{\mathrm{sw}}$. (b) Scores for PC3 largely reflect the difference benthic and planktonic $\delta^{18} \mathrm{O}_{\text {sw. }}$. Dashed black line marks linear trend from 0 to $430 \mathrm{ka}$.

LR04 global benthic stack with the sea level stack from 0 to $798 \mathrm{ka}$. One advantage of this comparison is that both records use the same age model. We evaluate whether a single regression can be used for the Late Pleistocene and identify a potential change in the relationship between benthic $\delta^{18} \mathrm{O}_{\mathrm{c}}$ and sea level at $\sim 400 \mathrm{ka}$.

One difference between the two stacks is that the sea level stack is smoother (Fig. 2), likely because some of the sea level records are low resolution and all records were interpolated to $1 \mathrm{ka}$ spacing for PCA. Smoothing the LR04 stack using a 7 ka running mean improves the correlation between benthic $\delta^{18} \mathrm{O}_{\mathrm{c}}$ and sea level from -0.90 to -0.92 . Additionally, we estimate the phase lag between the two records by measuring their correlation with different time shifts. This analysis suggests a $2 \mathrm{ka}$ phase lag between LR04 and the sea level stack, likely resulting from the fact that deep water temperature change leads ice volume change (e.g., Sosdian and Rosenthal, 2009; Elderfield et al., 2012; Shakun et al., 2015). When we apply this $2 \mathrm{ka}$ lag to the smoothed LR04 stack, its correlation with sea level improves to -0.94 .

Ordinary-least-squares linear regression between the smoothed-and-lagged LR04 benthic $\delta^{18} \mathrm{O}_{\mathrm{c}}$ stack $(x)$ and sea 
level in meters $(h)$ yields the equation

$h=-73 x+251$

(Fig. 4, black line). Using the bootstrapped PC1 samples described in Sect. 4.2 and Monte Carlo-style sampling of smoothing windows that range from 0 to $7 \mathrm{kyr}$ and lags from 0 to $3 \mathrm{kyr}$, we find that the $95 \% \mathrm{CI}$ for the slope of this regression is -56 to $-79 \mathrm{~m} \% \mathrm{o}^{-1}$. The root mean square error (RMSE) for this model is $10.7 \mathrm{~m}(95 \% \mathrm{CI}=9-22 \mathrm{~m})$, but the fit is better for the older portion of the record (398$798 \mathrm{ka}, \mathrm{RMSE}=10.2 \mathrm{~m})$ than the more recent portion $(0$ $397 \mathrm{ka}, \mathrm{RMSE}=11.2 \mathrm{~m}$ ). In particular, the linear model estimates sea levels that are 10-20 $\mathrm{m}$ too high during most highstands and lowstands back to MIS 10 at $\sim 345 \mathrm{ka}$. The difference in fit before and after $398 \mathrm{ka}$ is somewhat dependent upon the assumed lag between benthic $\delta^{18} \mathrm{O}$ and sea level; the linear model fits the older portion of the record better in $84 \%$ of samples with a $3 \mathrm{ka}$ lag but only $61 \%$ of sampled regressions with no lag. The effect of a smaller lag is mainly to increase the RMSE of the older portion of the linear regression from a mean of $12.7 \mathrm{~m}$ ( $3 \mathrm{ka} \mathrm{lag}$ ) to $15.7 \mathrm{~m}$ (no lag).

A plot of sea level versus the smoothed and lagged benthic $\delta^{18} \mathrm{O}_{\mathrm{c}}$ (Fig. 4b) suggests that the relationship between the two is approximately quadratic

$h=-26 x^{2}+135 x-163$

from 0 to $397 \mathrm{ka}(\mathrm{RMSE}=9.4 \mathrm{~m}, 95 \% \mathrm{CI}=8-22 \mathrm{~m})$ and linear from 398 to $798 \mathrm{ka}$. This transition appears to take place between 360 and $400 \mathrm{ka}$ because MIS 11 clearly falls on the linear trend whereas MIS 10 is a much better fit by the quadratic equation (Fig. 4a). Because this transition occurs after MIS 11, the extreme duration or warmth of this interglacial might have played an important role in the transition.

A change in the relationship between benthic $\delta^{18} \mathrm{O}_{\mathrm{c}}$ and sea level could be caused by a change in the mean isotopic content of ice sheets or the relationship between ice volume and deep water temperature (possibly also global surface temperature). Interglacials after MIS 11 were likely warmer or had more depleted $\delta^{18} \mathrm{O}_{\mathrm{sw}}$ relative to ice volume. Similarly, glacial maxima were probably warmer and/or had less $\delta^{18} \mathrm{O}_{\mathrm{sw}}$ change. Combined changes in temperature and isotopic fractionation may be the most likely explanation since warmer ice sheets also probably have less depleted $\delta^{18} \mathrm{O}_{\text {ice }}$. In fact Antarctic ice cores are isotopically less depleted during MIS 5e and MIS 9 than MIS 11 (Jouzel et al., 2007). Additionally, Antarctic surface temperatures and $\mathrm{CO}_{2}$ levels were similar for all three interglacials (Masson-Delmotte et al., 2010; Petit et al., 1999) despite the smaller ice volume during MIS 11.

There is little direct evidence to explain the changing relationship between $\delta^{18} \mathrm{O}_{\mathrm{c}}$ and sea level during glacial maxima because glacial values for both deep water temperature and the isotopic composition of Antarctic ice are similar throughout the last $800 \mathrm{ka}$ (Elderfield et al., 2012; Masson-Delmotte et al., 2010). The change in glacial maxima after $400 \mathrm{ka}$ could be caused by less depleted $\delta^{18} \mathrm{O}_{\text {ice }}$ in Northern Hemisphere $(\mathrm{NH})$ ice sheets. Although no long records of $\mathrm{NH} \delta^{18} \mathrm{O}_{\text {ice }}$ exist, global mean SST was $0.5-1{ }^{\circ} \mathrm{C}$ warmer during MIS 2, 6 , and 8 than during MIS 12 (Shakun et al., 2015). Alternatively, the apparent linear trend between sea level and $\delta^{18} \mathrm{O}_{\mathrm{c}}$ during glacial maxima before $400 \mathrm{ka}$ (Fig. 4c) could be an artifact of poor sea level estimates for MIS 12 and 16, which may be biased $10-20 \mathrm{~m}$ too high (Table 3 ) by missing data during sapropel intervals in the Mediterranean RSL record (Rohling et al., 2014).

In conclusion, a systematic relationship can be defined between Late Pleistocene benthic $\delta^{18} \mathrm{O}_{\mathrm{c}}$ and sea level, and the functional form of this relationship likely changed after MIS 11. Change in the $\delta^{18} \mathrm{O}_{\mathrm{c}}$-sea-level relationship during interglacials likely results from warmer high latitudes with less depleted $\delta^{18} \mathrm{O}_{\text {ice }}$ after $400 \mathrm{ka}$. Glacial maxima after $400 \mathrm{ka}$ may also have been warmer with less depleted $\mathrm{NH} \delta^{18} \mathrm{O}_{\text {ice }}$, but this apparent change during glacial maxima could be an artifact of bias in the sea level stack during MIS 12 and 16. Changes in the relationship between benthic $\delta^{18} \mathrm{O}_{\mathrm{c}}$ and sea level are also likely to have occurred during the early or mid-Pleistocene. For example, the same regression probably would not apply to the $41 \mathrm{ka}$ glacial cycles of the early Pleistocene (Tian et al., 2003).

\section{Differences between sea level proxies}

Whereas PC1 tells us about the common variance between the sea level proxies, PC2 and PC 3 tell us about their differences. PC2 represents 6 and $8 \%$ of the variance for the short and long time windows, respectively. The scores and loads are similar for both analyses (Fig. 5, Table 1) except for a sign change; therefore, we multiply by -1 the scores and loads of PC 2 and PC 3 of the short time window. Large PC2 loadings with opposite sign contributions for the 1123 and 607 benthic $\delta^{18} \mathrm{O}_{\text {sw }}$ records suggest that $\mathrm{PC} 2$ represents differences in the $\delta^{18} \mathrm{O}_{\mathrm{sw}}$ of deep water in the Atlantic and Pacific basins. Most notably, PC2 has a strong peak at approximately $250 \mathrm{ka}$ (Fig. 5), associated with very low values in the 607 benthic $\delta^{18} \mathrm{O}_{\mathrm{sw}}$ record and very high values in the 1123 benthic $\delta^{18} \mathrm{O}_{\text {sw }}$ record (Fig. 1).

PC 3 captures $5 \%$ of the variance in the $430 \mathrm{ka}$ stack and $6 \%$ of the variance in the 798 ka stack. Unlike PC1 and PC2, the loads vary between the short and long PC3 (Table 1); here we focus on the short version because it contains more proxy records. In the $430 \mathrm{ka}$ stack, PC3 is most highly represented by the planktonic $\delta^{18} \mathrm{O}_{\mathrm{sw}}$ stack with a load of -0.7 and the 1123 and 607 benthic $\delta^{18} \mathrm{O}_{\mathrm{sw}}$ records with loads of about 0.5 . These loads suggest that $\mathrm{PC} 3$ dominantly reflects planktonic versus benthic differences in $\delta^{18} \mathrm{O}_{\mathrm{sw}}$. PC3 scores exhibit a linear trend from 0 to $430 \mathrm{ka}$, which supports the findings of previous studies that suggest planktonic $\delta^{18} \mathrm{O}_{\mathrm{sw}}$ should be detrended for conversion to sea level (Lea et al., 2002; 
Shakun et al., 2015). Furthermore, PC3 suggests that benthic $\delta^{18} \mathrm{O}_{\mathrm{sw}}$ may also need to be detrended in the opposite direction. This effect could be caused by long-term changes in the hydrologic cycle or deep water formation processes, which lead to a change in the partitioning of oxygen isotopes between the surface and deep ocean.

\section{Conclusions}

PCA indicates a strong common sea level signal in the seven records analyzed for 0-430 ka and five records for 0-798 ka. Furthermore, the similarity between the short and long stacks indicates that the longer stack with five records is nearly as good an approximation of sea level as the seven-record stack. Sea level estimates for each interglacial vary greatly between records, producing standard deviations of 11-26 m. Generally, the mean for each individual highstand is greater in magnitude than our stack estimate. Based on comparison with GIA-corrected coral sea level estimates for MIS 5e and 11, the stack likely reflects mean sea level for each interglacial and fails to capture brief sea level highstands, such as those lasting only $\sim 2 \mathrm{ka}$ during MIS 5e (Kopp et al., 2013).

A comparison of individual records shows that highstand and lowstand estimates have a mean standard deviation of $17 \mathrm{~m}$ (for MIS 5e-19). Uncertainty in the stack is estimated using bootstrapping and random sampling, which yields a mean standard deviation for scaled PC1 of $9.4 \mathrm{~m}$ with seven records $(0-430 \mathrm{ka})$ and $12 \mathrm{~m}$ with five records $(0-798 \mathrm{ka})$. The bootstrap uncertainty estimates also include age uncertainty; however, this systematically smooths the bootstrap results and, thus, underestimates individual highstands relative to both individual records and scaled PC1 (Fig. 2c).

We estimate that sea level change accounts for only about $45 \%$ of the orbital-band variance in benthic $\delta^{18} \mathrm{O}_{\mathrm{c}}$, compared to $65 \%$ of the LGM-to-Holocene benthic $\delta^{18} \mathrm{O}_{\mathrm{c}}$ change. Nonetheless, benthic $\delta^{18} \mathrm{O}_{c}$ is strongly correlated with sea level $(r=-0.9)$. If LR04 benthic $\delta^{18} \mathrm{O}_{\mathrm{c}}$ stack is smoothed and lagged by $2 \mathrm{ka}$, the relationship between benthic $\delta^{18} \mathrm{O}_{\mathrm{c}}$ and sea level is well-described by a linear function from 398 to $798 \mathrm{ka}$ and a quadratic function from 0 to $398 \mathrm{ka}$. In particular, interglacials MIS 9 and 5e, which had larger ice sheets than MIS 11, appear to have been as warm (or warmer) as MIS 11 with isotopically less depleted ice sheets.

The second and third principal components of the sea level records describe differences between the proxies. PC2 represents the difference between the $\delta^{18} \mathrm{O}_{\text {sw }}$ of deep water in the Atlantic and Pacific basins; a peak in PC2 scores at $250 \mathrm{ka}$ indicates large differences between the basins at this time. PC3 represents the differences between planktonic and benthic $\delta^{18} \mathrm{O}_{\mathrm{sw}}$ records and suggests a linear trend between the two from 0 to $430 \mathrm{ka}$. Thus, $\delta^{18} \mathrm{O}_{\mathrm{sw}}$ records vary across ocean basins and between the surface and the deep. In conclusion, the stack of sea level proxies presented here should be a more accurate eustatic sea level record than any of the individual records it contains.

\section{Data availability}

The sea level stack is archived in the Supplement and at the World Data Center for Paleoclimatology operated by the National Climatic Data Center of the National Oceanographic and Atmospheric Association (https://www.ncdc.noaa.gov/ paleo/study/19982).

\section{The Supplement related to this article is available online at doi:10.5194/cp-12-1079-2016-supplement.}

Acknowledgements. We thank all researchers who made their data available. Additionally, we thank David Lea, Jeremy Shakun, Alex Simms, Charles Jones, and Leila Carvalho for beneficial discussions.

Edited by: E. Wolff

\section{References}

Abe-Ouchi, A., Saito, F., Kawamura, K., Raymo, M. E., Okuno, J., Takahashi, K., and Blatter, H.: Insolation-driven 100,000-year glacial cycles and hysteresis of ice-sheet volume, Nature, 500, 190-193, doi:10.1038/nature12374, 2013.

Adkins, J. F., McIntyre, K., and Schrag, D. P.: The Salinity, Temperature, and $\delta^{18} \mathrm{O}$ of the Glacial Deep Ocean, Science, 298, 17691773, doi:10.1126/science.1076252, 2002.

Andersen, M. B., Stirling, C. H., Potter, E. K., Halliday, A. N., Blake, S. G., Mc-Culloch, M. T., Ayling, B. F., and O'Leary, M.: High-precision U-series measurements of more than 500,000 year old fossil corals, Earth Planet. Sc. Lett., 265, 229-245, 2008.

Bard, E., Hamelin, B., Fairbanks, R. G., and Zindler, A.: Calibration of the ${ }^{14} \mathrm{C}$ timescale over the past 30,000 years using mass spectrometric U-Th ages from Barbados corals, Nature, 345, 405410, 1990.

Bard, E., Hamelin, B., Arnold, M., Montaggioni, L., Cabioch, G., Faure, G., and Rougerie, F.: Deglacial sea-level record from Tahiti corals and the timing of global meltwater discharge, Nature, 382, 241-244, doi:10.1038/382241a0, 1996.

Bates, S. L., Siddall, M., and Waelbroeck, C.: Hydrographic variations in deep ocean temperature over the midPleistocene transition, Quaternary Sci. Rev., 88, 147-158, doi:10.1016/j.quascirev.2014.01.020, 2014.

Bintanja, R., Roderik, S. W., and van de Wal, O. J.: Modeled atmospheric temperatures and global sea levels over the past million years, Nature, 437, 125-128, doi:10.1038/nature03975, 2005.

Blanchon, P., Eisenhauer, A., Fietzke, J., and Liebetrau, V.: Rapid sea-level rise and reef back-stepping at the close of the last interglacial highstand, Nature, 458, 881-884, doi:10.1038/nature07933, 2009. 
Boak, E. H. and Turner, I. L.: Shoreline Definition and Detection: A Review, J. Coastal Res., 214, 688-703, doi:10.2112/03-0071.1, 2005.

Bowen, D. Q.: Sea level 400000 years ago (MIS 11): analogue for present and future sea-level?, Clim. Past, 6, 19-29, doi:10.5194/cp-6-19-2010, 2010.

Bryden, H. L. and Kinder, T. H.: Steady two-layer exchange through the Strait of Gibraltar, Deep-Sea Res., 38, Supplement 1, S445S463, 1991.

Clark, P. U., Dyke, A. S., Shakun, J. D., Carlson, A. E., Clark, J., Wohlfarth, B., Mitrovica, J. X., Hostetler, S. W., and McCabe, A. M.: The Last Glacial Maximum, Science, 325, 710714, doi:10.1126/science.1172873, 2009.

Clark, P. U., Shakun, J. D., Baker, P. A., Bartlein, P. J., Brewer, S., Brook, E., Carlson, A. E., Cheng, H., Kaufman, D. S., Liu, Z., Marchitto, T. M., Mix, A. C., Morrill, C., Otto-Bliesner, B. L., Pahnke, K., Russell, J. M., Whitlock, C., Adkins, J. F., Blois, J. L., Clark, J., Colman, S. M., Curry, W. B., Flower, B. P., He, F., Johnson, T. C., Lynch-Stieglitz, J., Markgraf, V., McManus, J., Mitrovica, J. X., Moreno, P. I., and Williams, J. W.: Global climate evolution during the last deglaciation, P. Natl. Acad. Sci. USA, 109, E1134-E1142, doi:10.1073/pnas.1116619109, 2012.

Creveling, J. R., Mitrovica, J. X., Hay, C. C., Austermann, J., and Kopp, R. E.: Revisiting tectonic corrections applied to Pleistocene sea-level highstands, Quaternary Sci. Rev., 111, 72-80, doi:10.1016/j.quascirev.2015.01.003, 2015.

Duplessy, J. C., Labeyrie, L., and Waelbroeck, C.: Constraints on the ocean isotopic enrichment between the Last Glacial Maximum and the Holocene: Paleoceanographic implications, Quaternary Sci. Rev., 21, 315-330, 2002.

Dutton, A. and Lambeck, K.: Ice Volume and Sea Level During the Last Interglacial, Science, 337, 216-220, 2012.

Dutton, A., Carlson, A., Long, A., Milne, G., Clark, P., DeConto, R., Horton, B. P., Rahmstorf, S., and Raymo, M.: Sea-level rise due to polar ice-sheet mass loss during past warm periods, Science, 349, 6244, aaa4019-1, doi:10.1126/science.aaa4019, 2015.

Dwyer, G. S., Cronin, T. M., Baker, P. A., Raymo, M. E., Buzas, J. S., and Corrige, T.: North Atlantic Deepwater Temperature Change During Late Pliocene and Late Quaternary Climatic Cycles, Science, 270, 1347-1351, doi:10.1126/science.270.5240.1347, 1995.

Edwards, R. L., Beck, J. W., Burr, G. S., Donahue, D. J., Chappell, J. M. A., Bloom, A. L., Druffel, E. R. M., and Taylor, F. W.: A Large Drop in Atmospheric ${ }^{14} \mathrm{C} /{ }^{12} \mathrm{C}$ and Reduced Melting in the Younger Dryas, Documented with ${ }^{230}$ Th Ages of Corals, Science, 260, 962-968, 1993.

Elderfield, H., Ferretti, P., Greaves, M., Crowhurst, S. J., McCave, I. N., Hodell, D. A., and Piotrowski, A. M.: Evolution of ocean temperature and ice volume through the Mid-Pleistocene Climate Transition, Science, 337, 704-709, doi:10.1126/science.1221294, 2012.

Fairbanks, R. G.: A 17,000 year glacio-eustatic sea level record: influence of glacial melting rates on the Younger Dryas event and deep-ocean circulation, Nature, 342, 637-642, 1989.

Ganopolski, A. and Calov, R.: The role of orbital forcing, carbon dioxide and regolith in $100 \mathrm{kyr}$ glacial cycles, Clim. Past, 7, 1415-1425, doi:10.5194/cp-7-1415-2011, 2011.

Gibbons, F. T., Oppo, D. W., Mohtadi, M., Rosenthal, Y., Cheng, J., Liu, Z., and Linsley, B. K.: Deglacial $\delta^{18} \mathrm{O}$ and hydrologic variability in the tropical Pacific and Indian Oceans, Earth Planet. Sci. Lett., 387, 240-251, 2014.

Govin, A., Braconnot, P., Capron, E., Cortijo, E., Duplessy, J.-C., Jansen, E., Labeyrie, L., Landais, A., Marti, O., Michel, E., Mosquet, E., Risebrobakken, B., Swingedouw, D., and Waelbroeck, C.: Persistent influence of ice sheet melting on high northern latitude climate during the early Last Interglacial, Clim. Past, 8, 483-507, doi:10.5194/cp-8-483-2012, 2012.

Grant, K. M., Rohling, E. J., Bronk Ramsey, C., Cheng, H., Edwards, R. L., Florindo, F., Heslop, D., Marra, F., Roberts, A. P., Tamisiea, M. E., and Williams, F.: Sea-level variability over five glacial cycles, Nature Communications, 5, 5076, doi:10.1038/ncomms6076, 2014.

Hanebuth, T., Stattegger, K., and Grootes, P. M.: Rapid Flooding of the Sunda Shelf: A Late-Glacial Sea-Level Record, Science, 288, 1033-1035, doi:10.1126/science.288.5468.1033, 2000.

Hay, C., Mitrovica, J. X., Gomez, N., Creveling, J. R., Austermann, J., and Kopp, R. E.: The sea-level fingerprints of ice-sheet collapse during interglacial periods, Quaternary Sci. Rev., 87, 6069, doi:10.1016/j.quascirev.2013.12.022, 2014.

Horton, B. P.: Late Quaternary Relative Sea-level Changes in Midlatitudes, in: Encyclopedia of Quaternary Science, edited by: Elias, S. A., Elsevier, Boston, MA, 2064-3071, 2006.

Huybers, P. and Wunsch, C.: A depth-derived Pleistocene age model: Uncertainty estimates, sedimentation variability, and nonlinear climate change, Paleoceanography, 19, 1-24, doi:10.1029/2002PA000857, 2004.

Imbrie, J. and Imbrie, J. Z.: Modeling the climatic response to orbital variations, Science, 207, 943-953, 1980.

Jouzel, J., Masson-Delmotte, V., Cattani, O., Dreyfus, G., Falourd, S., Hoffmann, G., Minster, B., Nouet, J., Barnola, J. M., Chappellaz, J., Fischer, H., Gallet, J. C., Johnsen, S., Leuenberger, M., Loulergue, L., Luethi, D., Oerter, H., Parrenin, F., Raisbeck, G., Raynaud, D., Schilt, A., Schwander, A., Selmo, E., Souchez, R., Spahni, R., Stauffer, B., Steffensen, J. P., Stenni, B., Stocker, T. F., Tison, J. L., Werner, M., and Wolff, E. W.: Orbital and Millennial Antarctic Climate Variability over the Past 800,000 Years, Science 317, 793-796, doi:10.1126/science.1141038, 2007.

Kopp, R. E., Simons, F. J., Mitrovica, J. X., Maloof, A. C., and Oppenheimer M.: Probabilistic assessment of sea level during the last interglacial stage, Nature, 462, 863-867, doi:10.1038/nature08686, 2009.

Kopp, R. E., Simons, F. J., Mitrovica, J. X., Maloof, A. C., and Oppenheimer, M.: A probabilistic assessment of sea level variations within the last interglacial stage, Geophys. J. Int., 193, 711-716, 2013.

Lambeck, K., Rouby, H., Purcell, A., Sun, Y., and Sambridge, M.: Sea level and global ice volumes from the Last Glacial Maximum to the Holocene, P. Natl. Acad. Sci. USA, 111, 15296-15303, doi:10.1073/pnas.1411762111, 2014.

Lea, D. W., Martin, P. A., Pak, D. K., and Spero, H. J.: Reconstructing a $350 \mathrm{ky}$ history of sea level using planktonic $\mathrm{Mg} / \mathrm{Ca}$ and oxygen isotope records from a Cocos Ridge core, Quaternary Sci Rev., 21, 283-293, doi:10.1016/S0277-3791(01)00081-6, 2002.

Lisiecki, L. E. and Lisiecki, P. A.: Application of dynamic programming to the correlation of paleoclimate records, Paleoceanography, 17, 1049, doi:10.1029/2001PA000733, 2002. 
Lisiecki, L. E. and Raymo, M. E.: A Pliocene-Pleistocene stack of 57 globally distributed benthic $\delta^{18} \mathrm{O}$ records, Paleoceanography, 20, PA1003, doi:10.1029/2004PA001071, 2005.

Lisiecki, L. E. and Raymo, M. E.: Diachronous benthic $\delta^{18} \mathrm{O}$ responses during late Pleistocene terminations, Paleoceanography, 24, PA3210, doi:10.1029/2009PA001732, 2009.

Martin, P. A., Lea, D. W., Rosenthal, Y., Shackleton, N. J., Sarnthein, M., and Papenfuss, T.: Quaternary deep sea temperature histories derived from benthic foraminiferal $\mathrm{Mg} / \mathrm{Ca}$, Earth Planet. Sc. Lett., 198, 193-209, doi:10.1016/S0012821X(02)00472-7, 2002.

Masson-Delmotte, V., Stenni, B., Jouzel, J., Landais, A., Röthlisberger, R., Minster, B., Hansen, J., Pol, K., Barnola, J. M., Mikolajewicz, U., Braconnot, P., Chappellaz, J., Otto-Bliesner, B., Cattani, O., and Krinner, G.: EPICA Dome C record of glacial and interglacial intensities, Quaternary Sci. Rev., 29, 113-128, 2010.

Medina-Elizalde, M.: A global compilation of coral sea-level benchmarks: Implications and new challenges, Earth Planet. Sc. Lett., 362, 310-318, doi:10.1016/j.eps1.2012.12.001, 2013.

Muhs, D. R., Meco, J., Simmons, K. R.: Uranium-series ages of corals, sea level history, and palaeozoogeography, Canary Islands, Spain: An exploratory study for two Quaternary interglacial periods, Palaeogeogr. Palaeocl., 394, 99-118, doi:10.1016/j.palaeo.2013.11.015, 2014.

National Climatic Data Center: https://www.ncdc.noaa.gov/paleo/ study/19982, last access: 20 April 2016.

Petit, J. R., Jouzel, J., Raynaud, D., Barkov, N. I., Barnola, J.-M., Basile, I., Bender, M., Chappellaz, J., Davisk, M., Delaygue, G., Delmotte, M., Kotlyakov, V. M., Legrand, M., Lipenkov, V. Y., Lorius, C., Pépin, L., Ritz, C., Saltzman, E., and Stievenard, M.: Climate and atmospheric history of the past 420,000 years from the Vostok ice core, Antarctica, Nature, 399, 429-436, 1999.

Raymo, M. E. and Mitrovica, J. X.: Collapse of polar ice sheets during the stage 11 interglacial, Nature, 483, 453-456, doi:10.1038/nature10891, 2012.

Raymo M. E., Ruddiman W. F., Shackleton N. J., and Oppo D. W.: Evolution of Atlantic Pacific $\delta^{13} \mathrm{C}$ Gradients over the Last 2.5 My, Earth Planet. Sc. Lett., 97, 353-368, 1990.

Rohling, E. J., Grant, K., Bolshaw, M., Roberts, A. P., Siddall, M., Hemleben, C., and Kucera, M.: Antarctic temperature and global sea level closely coupled over the past five glacial cycles, Nat. Geosci., 2, 500-504, 2009.

Rohling, E. J., Grant, K. M., Bolshaw, M., Roberts, A. P., Siddall, M., Hemleben, C., Kucera, M., Foster, G. L., Marino, G., Roberts, A. P., Tamisiea, M. E., and Williams, F.: Sea-level and deep-sea-temperature variability over the past 5.3 million years, Nature, 508, 477-482, 2014.

Schiebel, R., Zeltner, A., Treppke, U. F., Waniek, J. J., Bollmann, J., Rixen, T., and Hemleben, C.: Distribution of diatoms, coccolithophores and planktic foraminifera in the Arabian Sea, Mar. Micropaleontol., 51, 345-371, doi:10.1016/j.marmicro.2004.02.001, 2004.
Shackleton, N. J.: Attainment of isotopic equilibrium between ocean water and the benthonic foraminifera genus Uvigerina: Isotopic changes in the ocean during the last glacial, in: Colloques internationaux, Centre national de la recherche scientifique, France, 219, 203-209, 1974.

Shakun, J. D., Lea, D. W., Lisiecki, L. E., and Raymo, M. E.: An 800-kyr record of global surface ocean $\delta^{18} \mathrm{O}$ and implications for ice volume-temperature coupling, Earth. Planet. Sc. Lett., 426, 58-68, 2015.

Siddall, M., Smeed, D. A., Hemleben, Ch., Rohling, E. J., Schmeltzer, I., and Peltier, W. R.: Understanding the Red Sea response to sea level, Earth. Planet. Sc. Lett., 225, 421-434, 2004.

Siddall, M., Hönisch, B., Waelbroeck, C., and Huybers, P.: Changes in deep Pacific temperature during the mid-Pleistocene transition and Quaternary, Quaternary Sci. Rev., 29, 170-181, 2010.

Skinner, L. C. and Shackleton, N. J.: An Atlantic lead over Pacific deep-water change across Termination I: implications for the application of the marine isotope stage stratigraphy, Quaternary Sci. Rev., 24, 571-580, doi:10.1016/j.quascirev.2004.11.008, 2005.

Sosdian, S. and Rosenthal, Y.: Deep-Sea Temperature and Ice Volume Changes Across the Pliocene-Pleistocene Climate Transitions, Science, 325, 306-310, doi:10.1126/science.1169938, 2009.

Stein, M., Wasserburg, G. J., Aharon, P., Chen, J. H., Zhu, Z. R., Bloom, A., and Chappell, J.: TIMS U-series dating and stable isotopes of the last interglacial event in Papua New Guinea, Geochimica et Cosmochimica Acta, 57, 11, 2541-2554, doi:10.1016/0016-7037(93)90416-T, 1993.

Stern, J. V. and Lisiecki, L. E.: Termination 1 timing in radiocarbon dated regional benthic $\delta^{18} \mathrm{O}$ stacks, Paleoceanography, 29, 11271142, doi:10.1002/2014PA002700, 2014.

Stirling, C. H., Esat, T. M., McCulloch, M. T., and Lambeck, K.: High-precision U-series dating of corals from Western Australia and implications for the timing and duration of the Last Interglacial, Earth Planet. Sc. Lett., 135, 115-130 doi:10.1016/0012821X(95)00152-3, 1995.

Thompson, W. G. and Goldstein, S. L.: Open-System Coral Ages Reveal Persistent Suborbital Sea-Level Cycles, Science, 308, 401-404, doi:10.1126/science.1104035, 2005.

Tian, L., Yao, T., Schuster, P. F., White, J. W. C., Ichiyanagi, K., Pendall, E., Pu, J., and Yu, W.: Oxygen-18 concentrations in recent precipitation and ice cores on the Tibetan Plateau, J. Geophys. Res., 108, 4293, doi:10.1029/2002JD002173, 2003.

Waelbroeck, C., Labeyrie, L., Michel, E., Duplessy J.C., McManus J.: Sea-level and deep water temperature changes derived from benthic foraminifera isotopic records, Quaternary Sci. Rev., 21, 295-305, 2002.

Wang, P., Tian, J., and Lourens, L. J.: Obscuring of long eccentricity cyclicity in Pleistocene oceanic carbon isotope records, Earth Planet. Sci. Lett., 290, 319-330, 2010. 